\title{
Urticaria and angioedema
}

\author{
G Spickett \\ Consultant Clinical Immunologist, Regional Department of Immunology, Royal Victoria Infirmary, Newcastle-upon-Tyne, UK
}

\begin{abstract}
Urticaria, also known as hives, and angioedema, where the swelling occurs below the skin instead of on the skin, are extremely common but there is a misconception that the most likely cause is an allergic reaction. Chronic urticaria in particular is rarely due to allergy. Equally for angioedema, many will consider the exceptionally rare hereditary angioedema (HAE), but in fact other medical causes are the most likely, in particular the use of angiotensin-converting enzyme inhibitor (ACE-I) drugs. Approximately 3-5\% of patients receiving ACE-I will develop angioedema at some time in the course of their treatment.' Stress is a major contributor to both chronic urticaria and recurrent angioedema. Treatment needs to focus on the use of long-acting, non-sedating, antihistamines. Corticosteroids may be used acutely but not long term.
\end{abstract}

Correspondence to G Spickett Regional Department of Immunology

Royal Victoria Infirmary

Newcastle-upon-Tyne

NEI 4LP, UK

tel $+44(0) 1912825517$

e-mail

Gavin.Spickett@nuth.nhs.uk

KEYWORDS Urticaria, angioedema, mastocytosis, antihistamines, $\mathrm{Cl}$-esterase inhibitor deficiency

DECLARATIONS OF INTERESTS No conflicts of interest declared.

\section{OVERVIEW}

Urticaria is extremely common, with up to $20 \%$ of people developing urticaria at some point in their life. ${ }^{2}$ It is characterised by a red, raised, itchy rash resulting from vasodilatation, increased blood flow, and increased vascular permeability, consequent upon mediator release from mast cells. Urticarial wheals can vary in size from a few millimetres to large lesions (10-20 centimetres), which may be single or numerous, and are intensely itchy. While urticaria occurs in the superficial dermis, angioedema refers specifically to localised deep-tissue swelling.

\section{PATHOPHYSIOLOGY}

Urticaria is usually divided into acute and chronic forms. Chronic is defined as daily, or almost daily, symptoms for more than six weeks. Chronic urticaria and angioedema affects $0.5-1.0 \%$ of the population. Urticaria may occur alone (50\% of cases) or with angioedema ( $40 \%$ of cases). Angioedema alone occurs in about $10 \%$ of the population. The causes are very similar.The majority of patients with chronic urticaria will have evidence of dermographism ('skin writing', when firm pressure on the skin of the forearm with a blunt tool causes the rash to develop in that area); this indicates a physical urticaria but is also often a marker of other medical problems such as iron deficiency and stress.

Many cases are referred to immunology and allergy units for investigation of possible food allergies after presentation to emergency departments. The timing of reactions in respect to food consumption is crucial in deciding whether this is a likely cause. Acute food reactions will mostly be immediate or within two hours of eating, and only rarely occur after longer times. Urticarial or angioedematous reactions the next day will not be connected with food (Table I).

The lesions of urticaria are usually caused by histamine, released by mast cells. While this can be due to immunoglobulin $\mathrm{E}$ ( $\mathrm{IgE})$-mediated phenomena, it can also be triggered by neurogenic reflexes and by direct stimulation, for example by opiates or strawberries. Angioedema, however, is caused mainly by the release of bradykinin, through activation in the fluid phase of the kinin cascade. Infection and trauma are potent triggers for kinin production. This explains the link between ACE-I and angioedema: the drugs inhibit the breakdown of bradykinin, but if there is no source of bradykinin in the first place then no angioedema will occur. Hence there must be another significant bradykinin-producing event before angioedema will occur. Patients may therefore have been on the drug for many years without problems before the angioedema occurs. Once it has happened however, it is advisable to discontinue the drug and substitute an angiotensin-II receptor-blocking drug (ARB), which have similar cardiovascular benefits but do not interfere with bradykinin metabolism. Leukotriene and complement breakdown products are also involved in persistent lesions of both urticaria and angioedema. A small proportion of patients may have autoantibodies, including antibodies against the $\lg \mathrm{E}$ receptor on mast cells; such patients may have particularly persistent urticaria that is difficult to control without 
TABLE I Causes of non-allergic urticaria and angioedema

\begin{tabular}{|c|c|}
\hline $\begin{array}{l}\text { Urticaria or urticaria } \\
\text { with angioedema }\end{array}$ & Angioedema alone \\
\hline $\begin{array}{l}\text { Stress (commonest, } \\
\text { approximately } 50-70 \% \text { of } \\
\text { cases) }\end{array}$ & Stress (commonest) $)^{3}$ \\
\hline $\begin{array}{l}\text { Infections (viral, bacterial } \\
\text { [consider Helicobacter], } \\
\text { chronic cholecystitis, dental } \\
\text { infection, sinus infection) }\end{array}$ & $\begin{array}{l}\text { Infections (viral, bacterial } \\
\text { [consider Helicobacter], } \\
\text { chronic cholecystitis, dental } \\
\text { infection, sinus infection) }\end{array}$ \\
\hline $\begin{array}{l}\text { Physical (pressure, delayed } \\
\text { pressure, water, sunlight, } \\
\text { vibration, heat/cold) }\end{array}$ & $\begin{array}{l}\text { Hereditary angioedema } \\
\text { (HAE) due to deficiency of } \\
\mathrm{Cl} \text {-esterase inhibitor (low } \\
\mathrm{C} 4 \text { during attacks; reduced } \\
\mathrm{Cl} \text {-esterase inhibitor or } \\
\text { function) }\end{array}$ \\
\hline $\begin{array}{l}\text { Drug induced (almost } \\
\text { any, but particularly non- } \\
\text { steroidal anti-inflammatory } \\
\text { drugs [NSAIDs], opiates) }\end{array}$ & $\begin{array}{l}\text { Drug induced (ACE-I, } \\
\text { statins,proton pump } \\
\text { inhibitors [PPIs], NSAIDs) }\end{array}$ \\
\hline $\begin{array}{l}\text { Dietary (rare - consider } \\
\text { salicylates) }\end{array}$ & $\begin{array}{l}\text { Acquired angioedema } \\
\text { (AAE), associated with } \\
\text { paraproteins: myeloma, } \\
\text { lymphoma, especially splenic } \\
\text { villous lymphoma }\end{array}$ \\
\hline $\begin{array}{l}\text { Vitamin deficiency (iron, } \\
\text { folate, } \mathrm{B} \mid 2 \text { ) }\end{array}$ & \\
\hline $\begin{array}{l}\text { Thyroid disease (especially } \\
\text { associated with thyroid } \\
\text { peroxidase antibodies) }\end{array}$ & \\
\hline Liver disease & \\
\hline $\begin{array}{l}\text { Chronic inflammatory } \\
\text { disease (e.g. rheumatoid } \\
\text { arthritis) }\end{array}$ & \\
\hline $\begin{array}{l}\text { Mastocytosis (urticaria } \\
\text { pigmentosa) - rare but } \\
\text { check mast cell tryptase }\end{array}$ & \\
\hline $\begin{array}{l}\text { Autoimmune } \\
\text { (autoantibodies to } \\
\text { immunoglobulin gE [lgE] Fc } \\
\text { receptor on mast cells) }\end{array}$ & \\
\hline $\begin{array}{l}\text { With vasculitis } \\
\text { (hypocomplementaemic } \\
\text { urticarial vasculitis } \\
\text { [HUVS], associated with } \\
\text { autoantibodies to } \mathrm{Clq} \text { ) }\end{array}$ & \\
\hline $\begin{array}{l}\text { Cholinergic (multiple small } \\
\text { round lesions, typically on } \\
\text { upper chest, associated with } \\
\text { heat and exercise) }\end{array}$ & \\
\hline $\begin{array}{l}\text { Idiopathic - no cause } \\
\text { identified }\end{array}$ & $\begin{array}{l}\text { Idiopathic - no cause } \\
\text { identified }\end{array}$ \\
\hline
\end{tabular}

recourse to immunosuppressive agents. Urticarial vasculitis is associated with antibodies against complement $\mathrm{Clq}$, which lead to persistent complement activation: low $\mathrm{Clq}$ and $\mathrm{C} 3$ and $\mathrm{C} 4$ will be found.
Hereditary angioedema (HAE) due to $\mathrm{Cl}$-esterase inhibitor deficiency is an autosomal dominant condition. A total of $90 \%$ of cases are due to type I with low or absent $\mathrm{Cl}$-esterase inhibitor levels; the remaining 10\% are due to point mutations in the active site of the enzyme which lead to high or high normal levels of $\mathrm{Cl}$-esterase inhibitor but low or absent function. ${ }^{2} \mathrm{~A}$ third type of HAE is due to gain-of-function mutations in clotting factor XII; this is extremely rare. Attacks of HAE are often triggered by trauma, infections, stress, pregnancy, and the use of hormonal contraceptives. In contrast to other types of angioedema, the attacks are slow to develop. Urticaria occurs only rarely. Attacks may affect any part of the body but may affect the larynx (this is less common with other types of angioedema) and may affect the bowel, presenting to surgeons as an acute abdomen. Surgery should be avoided if at all possible, unless there is very clear evidence of pathology separate from abdominal angioedema. Recurrent laparotomy is unhelpful to the patient. CT scanning may identify bowel oedema. Idiopathic angioedema is more likely to present in the night or on waking, possibly due to $\mathrm{pH}$ changes in serum overnight. Presentation on waking (after a prolonged fast) makes it extremely unlikely that foods are involved.

Acquired angioedema (AAE) is usually seen in an older group of patients and is typically associated with splenic villous lymphoma (the spleen will be enlarged) or with myeloma. The paraprotein contains anti-Cl-esterase inhibitor activity (tests are available at reference centres for this). The angioedema may precede the overt development of the lymphoma. Similar autoantibodies against $\mathrm{Cl}$-esterase inhibitor can be seen very rarely in systemic lupus erythematosus.

Patients who describe cold urticaria fall into two types: most commonly it is straightforward physical urticaria, and an ice cube test will be positive (see below); much rarer is familial cold autoinflammatory syndrome (FCAS), associated with defects in the gene encoding cryopyrin. Here the cold-induced urticaria is associated with headaches, systemic malaise, rigors, conjunctivitis, and arthralgia. Often other family members are also affected.

\section{DIAGNOSIS AND TESTING}

Diagnosis is dependent on the nature of the lesions. If nothing is visible at the time of the consultation, encourage the patient to take photos (mobile phones are a huge medical benefit) to document the appearance. The lesions of urticarial vasculitis typically last in one place for more than 24 hours and often fade, leaving brown discoloration. A biopsy will confirm the presence of vasculitis if there is doubt. A careful history and full examination is required, with particular attention to teeth, sinuses, gallbladder and liver, spleen, and lymph nodes, as these are sites of potential unrecognised 
infection. Always test for dermographism. Consider an ice cube test for cold-associated symptoms. In this test, a short application of an ice cube to the forearm leads to an immediate wheal and flare response, corresponding to the shape of the ice cube (the ice cube should be in a plastic bag to stop cold water running all over the arm and causing widespread whealing).

Testing should be determined by the presentation and clinical findings. As a general rule, basic investigations should include full blood count, inflammatory markers (for infection, inflammation), liver function, thyroid function, ferritin level, folate and $\mathrm{BI} 2$ and thyroid peroxidase antibodies. 'Allergy tests' are rarely of value but mast cell tryptase is useful, if levels are persistently elevated, in diagnosing mastocytosis. Other tests that may be considered include serum immunoglobulins and electrophoresis (looking for paraproteins in acquired angioedema), cryoglobulins (cold-induced symptoms) and complement $\mathrm{C} 3$ and $\mathrm{C4}$. $\mathrm{Cl}$-esterase inhibitor measurement should be taken if the $\mathrm{C} 4$ is low, and should include a functional test. A stool antigen test for Helicobacter may be helpful if there are gastrointestinal symptoms. Imaging should be determined by clinical suspicion.

\section{MANAGEMENT}

The management of urticaria and angioedema depends to a certain extent on the underlying cause. Correctable causes should be treated. Low iron stores, even if the haemoglobin and mean corpuscular volume (MCV) are normal may be enough to trigger urticaria, so replacement of iron is always indicated and reasons for low iron (menstrual loss, diet, and malabsorption [e.g. coeliac disease]) should be sought. Infection should be identified and treated.

The basis of management of urticaria is long-acting, non-sedating antihistamines. Sometimes a simple switch to a different non-sedating antihistamine may be helpful. Fexofenadine has a higher strength tablet $(180 \mathrm{mg})$ licensed for use in urticaria. The dose of non-sedating antihistamines may need to be above those recommended in the British National Formulary (BNF). Cetirizine, for example, may be used in doses up to 60 $\mathrm{mg} /$ day in divided doses and fexofenadine up to $720 \mathrm{mg} /$ day in divided doses.These dosage regimes are unlicensed. Current antihistamines have been checked for cardiovascular safety. Older antihistamines have been associated with torsade de pointes ventricular arrhythmia, subsequently found to be due to interference with cardiac potassium channels. Sedating antihistamines chlorphenamine and hydroxyzine should only be used at night. Tricyclic antidepressants have useful antihistaminic properties and can be effective, particularly where stress is a major contributor. They are, however, sedating. Anti- $\mathrm{H} 2$ drugs may be added and can occasionally help.
TABLE 2 Stepped treatment of urticaria and angioedema. This assumes that treatable causes have been identified and dealt with fully and that rare causes have been identified

\begin{tabular}{|l|l|l|}
\hline Step & $\begin{array}{l}\text { Urticaria without } \\
\text { angioedema }\end{array}$ & $\begin{array}{l}\text { Urticaria with } \\
\text { angioedema }\end{array}$ \\
\hline I & $\begin{array}{l}\text { Non-sedating long-acting } \\
\text { antihistamine (cetirizine, } \\
\text { fexofenadine etc.) }\end{array}$ & $\begin{array}{l}\text { Non-sedating long-acting } \\
\text { antihistamine (cetirizine, } \\
\text { fexofenadine etc.) }\end{array}$ \\
\hline 2 & $\begin{array}{l}\text { Increase dose of } \\
\text { antihistamine; add } \\
\text { sedating antihistamine } \\
\text { at night }\end{array}$ & $\begin{array}{l}\text { Increase dose of } \\
\text { antihistamine; add } \\
\text { sedating antihistamine } \\
\text { at night }\end{array}$ \\
\hline 3 & $\begin{array}{l}\text { Is stress a contributor? } \\
\text { Consider doxepin, } \\
\text { mirtazapine or other } \\
\text { selective serotonin } \\
\text { reuptake inhibitor (SSRI) }\end{array}$ & $\begin{array}{l}\text { Is stress a contributor? } \\
\text { Consider doxepin } \\
\text { mirtazipine, or other } \\
\text { SSRI }\end{array}$ \\
\hline 4 & $\begin{array}{l}\text { Add H2-blocking drug } \\
\text { (cimetidine preferred) }\end{array}$ & $\begin{array}{l}\text { Add tranexamic acid } \\
\text { at mid-dose (I g twice } \\
\text { daily) }\end{array}$ \\
\hline 5 & $\begin{array}{l}\text { Switch H2-blocker } \\
\text { for montelukast or } \\
\text { zafirlukast }\end{array}$ & $\begin{array}{l}\text { Increase dose of } \\
\text { tranexamic acid to } \\
\text { maximum - I g four } \\
\text { times a day }\end{array}$ \\
\hline 6 & $\begin{array}{l}\text { Consider alternates: } \\
\text { calcium channel, } \\
\text { aminophylline, } \\
\text { terbutaline }\end{array}$ & $\begin{array}{l}\text { Consider modified } \\
\text { androgen in place of } \\
\text { tranexamic acid }\end{array}$ \\
tacrolimus & $\begin{array}{l}\text { Consider intravenous } \\
\text { immunoglobulin or } \\
\text { omalizumab }\end{array}$ & onsider ciclosporin or \\
\hline 7
\end{tabular}

Cimetidine is preferred because it also has immunosuppressive properties. Leukotriene antagonists such as montelukast and zafirlukast are also recommended as second-line agents, but rarely seem to be effective. Mirtazapine can be very effective. Calcium channel blockers can also be beneficial. The approach to stepped care is outlined in Table 2 .

Corticosteroids should be used only as emergency doses for acute events. Chronic steroid therapy is to be avoided as subsequent withdrawal is difficult, with severe flares the rule.

Immunosuppressive drugs may be used. Ciclosporin may be valuable, as it also inhibits basophils and mast cell degranulation. Tacrolimus is an alternative. Urticarial vasculitis may respond to hydroxychloroquine, colchicine, dapsone (check glucose-6-phosphate dehydrogenase deficiency [G6PD] first), sulphasalazine, or methotrexate. All of these drugs require regular blood monitoring. Annual eye checks are required for people taking hydroxychloroquine (due to the risk of retinal damage). Omalizumab is undergoing clinical trials and may be 
promising, although not curative. The precise mechanisms of actions of some of these drugs in urticaria are not known, and it is advisable to seek specialist advice before introducing them.

Topical therapies such as doxepin cream, which has potent anti-HI and anti-H2 antihistaminic activity, or menthol in aqueous cream, which provides marked cooling through its effect on local nerves can provide some symptomatic relief.

Angioedema not due to $\mathrm{HAE}$ or AAE may respond to antihistamines, but if it does not and no cause is identified, prophylaxis with tranexamic acid is effective (with monitoring of liver function and liver ultrasound). Modified androgens such as danazol and stanozolol are potential alternatives but are poorly tolerated in women, because of the androgenic effects (which will affect all women) and have much greater risks of liver toxicity, particularly hepatocellular carcinoma, the risk of which increases with duration of therapy.

Angioedema due to $\mathrm{HAE}$ can be prevented with tranexamic acid or modified androgens. If attacks are frequent or severe, then prophylaxis with intravenous $\mathrm{Cl}$-esterase inhibitor is appropriate, but must be given weekly. Acute attacks can be treated with intravenous $\mathrm{Cl}$-esterase inhibitor or with icatibant, a bradykinin B2 antagonist, which is administered subcutaneously. The latter will also be licenced for other types of angioedema in 2014 All such patients must be under the care of an immunologist or allergist as indicated in the guidance for specialist commissioning in the NHS.

\section{REFERENCES}

I Nia AM, Er F.Angioedema associated with the use of angiotensinconverting enzyme inhibitor. CMAJ 20I3; 185:E80. http://dx.doi. org/I0.1503/cmaj. I II387

2 Kaplan AP. Urticaria and angioedema. In: Franklin Adkinson Jr N Busse WW, Bochner BS et al, editors. Middleton's allergy. Principles and practice. 7th edition. Philadelphia: Mosby Elsevier; 2009. PP. |063-8I. http://dx.doi.org/I0.I0I6/B978-0-323-05659-5.0006 I-9

3 Personal observations and Ben-Shoshan M, Blinderman I, Raz A. Psychosocial factors and chronic spontaneous urticaria: a systematic review. Allergy 2013; 68: I3 I-4I. http://dx.doi.org/I0.I I I I/all.I2068
Adrenaline is only required where there is clear evidence of systemic symptoms (hypotension, laryngeal obstruction, bronchospasm). Patients should not be given adrenaline for self-injection unless they have had severe systemic symptoms.

Where there is a poor response to the highest levels of treatment, continually re-evaluate the patient for alternative diagnoses. Consider the use of psychological therapies.

Patients with cold-induced urticaria need to be warned not to expose large areas of skin to sudden cooling as this can trigger massive and lethal histamine release: this includes swimming or winter sports.

\section{CONCLUSIONS}

The key points are as follows: the commonest causes of chronic spontaneous urticaria are stress, infections and other medical problems. IgE-mediated allergy is a rare cause of chronic spontaneous urticaria. Hereditary angioedema is a rare cause of spontaneous angioedema. ACE-inhibitors are a common cause of angioedema without urticaria. High dose antihistamines are preferable to corticosteroids for management of urticaria.

Highlights

- The commonest cause of chronic urticaria is stress.

- Physical urticaria may be a marker of underlying medical problems and stress.

- Chronic urticaria is rarely due to 'allergy' and allergy tests are not necessary.

- Angioedema is caused by excessive bradykinin release; ACE inhibitors prevent the breakdown of bradykinin.

- The mainstay of management of urticaria is treatment with long-acting non-sedating antihistamines if necessary in increased doses (unlicensed indication).

- Corticosteroids should only be used for acute not chronic treatment.

\section{FURTHER READING}

I Best Practice Advocacy Centre (New Zealand). Diagnosis and treatment of urticarial. BPJ 2012; 43:6-13.

2 Grattan $\mathrm{CEH}$, Humphreys F, on behalf of the British Association of Dermatologists Therapy Guidelines and Audit Subcommittee. Guidelines for evaluation and management of urticaria in adults and children. $\mathrm{Br} J$ Dermatol 2007; 157:I | |6-23. http://dx.doi. org/I0.IIII/j. I365-2I33.2007.08283.x

3 Kaplan AP. Treatment of chronic spontaneous urticaria. Allergy Asthma Immunol Res 20I2; 4:326-3I. http://dx.doi.org/I0.4I68/ aair.20I2.4.6.326

4 Powell RJ, Du Toit GL, Siddique WN et al. BSACl guidelines for the management of chronic urticaria and angio-oedema. Clin Exp Allergy 2007; 37:63 I-50. http://dx.doi.org/I0. I I I I/j. I365-2222.2007.02678.x

5 Zuberbier T, Asero R, Bindslev-Jensen C et al. EAACI/GA(2)LEN/ EDF/WAO guideline: management of urticarial. Allergy 2009; 64: I427-43. http://dx.doi.org/I0.I I I //j.I398-9995.2009.02 I78.x 


\section{SELF-ASSESSMENT QUESTIONS}

I. A 32-year-old woman presents with urticaria of three months duration. She gets attacks most days, especially at night and in the shower. She has tried cutting wheat and dairy out of her diet. She has heavy and prolonged periods, with flooding. What ONE of the following is the most likely underlying cause of her urticaria?
A. Salicylate intolerance.
B. Food allergy.
C. Iron deficiency.
D. Heat intolerance.
E. Idiopathic.

2. Which ONE of the following is the main cause of angioedema?
A. Histamine.
B. Leukotrienes.
C. Complement breakdown products.
D. Tryptase.
E. Bradykinin.

3. Which ONE of the following is the main cause of hereditary angioedema?

A Autoantibodies to $\mathrm{Clq}$.

B. Deficiency of $\mathrm{Cl}$-esterase inhibitor.

C. Gain of function mutation in factor VIII.

D. Mutations in the $\mathrm{Fc}$ receptor for IgE on mast cells.

E. IgG autoantibodies to $\mathrm{Cl}$-esterase inhibitor.
4. Which ONE of the following sets of investigations would be most appropriate in a young female adult patient with severe chronic urticaria?

A. FBC, ESR, LFTs, TFTs, ferritin, BI2, folate, tryptase.

B. FBC, ESR, LFTs, TFTs, ferritin, immunoglobulins.

C. FBC, ESR, LFTs, TFTs, ferritin, RAST tests, complement C3, C4, tryptase.

D. FBC, ESR, LFTs, TFTs, ferritin, tryptase, autoantibody screen.

E. FBC, ESR, LFTs, TFTs, CRP.

5. A 35-year-old male with chronic urticaria without angioedema is referred to the clinic.

Dermographism is demonstrated despite the fact that he is taking cetirizine $10 \mathrm{mg}$ daily. What would the next step be in his treatment plan?

A. Switch to chlorphenamine $4 \mathrm{mg}$ po qds.

B. Start prednisolone $40 \mathrm{mg}$ daily and taper down to a maintenance dose of $5 \mathrm{mg}$ daily.

C. Increase the cetirizine in steps up to $40 \mathrm{mg}$ per day in divided doses.

D. Add ranitidine $150 \mathrm{mg}$ bd to his current dose of cetirizine.

E. Start tranexamic acid I g bd.

This paper was originally published as part of the Immunology module in the RCPE Online Continuing Medical Education Programme. Online CME, including the anwers to these questions, is available to Fellows and Members at: http://www.rcpe.ac.uk 